\title{
Apoptosis and differentiation commitment: novel insights revealed by gene profiling studies in mouse embryonic stem cells
}

\author{
D Duval ${ }^{1,2,4}$, M Trouillas $^{3,4}$, C Thibault ${ }^{2}$, D Dembelé ${ }^{2}$, \\ F Diemunsch ${ }^{2}$, B Reinhardt ${ }^{2}$, AL Mertz $^{2}$, A Dierich $^{2}$ \\ and $\mathrm{H}$ Bœuf ${ }^{*, 3}$ \\ 1 UMR5096-CNRS/UP/IRD, Perpignan, France \\ 2 IGBMC/CNRS/INSERM, Strasbourg, France \\ ${ }^{3}$ UMR-5164-CNRS-CIRID/Université Bordeaux2, Bordeaux, France \\ 4 These authors contributed equally to this work \\ * Corresponding author: H Bœuf, UMR-5164-CNRS-CIRID, Université \\ Bordeaux2, Bat.1B, BP14, 146 rue Léo Saignat, 33076 Bordeaux, France. \\ Tel: + 05575746 33; Fax: + 05575714 72; \\ E-mail:helene.bœuf@u-bordeaux2.fr
}

Received 10.3.05; revised 01.9.05; accepted 01.9.05; published online 25.11.05 Edited by R De Maria

\begin{abstract}
Mouse embryonic stem (ES) cells remain pluripotent in vitro when grown in the presence of leukemia inhibitory factor (LIF). LIF starvation leads to apoptosis of some of the ESderived differentiated cells, together with $\mathrm{p} 38 \alpha$ mitogenactivated protein kinase (MAPK) activation. Apoptosis, but not morphological cell differentiation, is blocked by a p38 inhibitor, PD169316. To further understand the mechanism of action of this compound, we have identified its specific targets by microarray studies. We report on the global expression profiles of genes expressed at 3 days upon LIF withdrawal (d3) compared to pluripotent cells and of genes whose expression is modulated at $\mathrm{d} 3$ under anti-apoptotic conditions. We showed that at $\mathrm{d} 3$ without LIF cells express, earlier than anticipated, specialized cell markers and that when the apoptotic process was impaired, expression of differentiation markers was altered. In addition, functional tests revealed properties of anti-apoptotic proteins not to alter cell pluripotency and a novel role for metallothionein 1 gene, which prevents apoptosis of early differentiated cells.

Cell Death and Differentiation (2006) 13, 564-575.

doi:10.1038/sj.cdd.4401789; published online 25 November 2005
\end{abstract}

Keywords: mouse ES cells; apoptosis; p38; PD169316; $\mathrm{Ca}^{2+}$ binding proteins; metallothionein; stress-response

Abbreviations: AlF, apoptosis-inducing factor; BMP, bone morphogenetic protein; Casp3, caspase 3; Cdc7, cell division cycle 7; cns, COP9 signalosome; ES, embryonic stem; FGF, fibroblast growth factor; foxD3, forkhead box D3; ICM, inner cell mass; Jab1, Jun activation domain-binding protein 1; LIF, leukemia inhibitory factor; MAPK, mitogen-activated protein kinase; Met, metallothionein; Oct, octamer; TGF, transforming growth factor; Tif 1, transcriptional intermediary factor 1

\section{Introduction}

Mouse embryonic stem (ES) cells, which are maintained pluripotent in vitro with leukemia inhibitory factor (LIF) cytokine, are instrumental to study LIF-dependent cell pluripotency as well as the first steps of differentiation commitment triggered upon LIF starvation. As we recently reported, these cells could also be used to unravel the early steps of apoptosis, a physiological cell death process occurring during the first embryogenesis stages. Indeed, the formation of the cavities, which starts at the blastocyst stage, is dependent on a specific cell death program, which includes caspase 3 cleavage and induction of the apoptosis-inducing factor (AIF)-complex proteins. ${ }^{1}$ The importance of bone morphogenetic protein (BMP) proteins to stimulate apoptosis at the early epiblast stage ${ }^{2}$ and the reverse effect of TGF $\alpha$ signaling for survival of preimplantation embryo ${ }^{3}$ have also been demonstrated. In addition, gene targeted studies in mice shed light on specific functions of embryonic markers expressed at the preimplantation stages. Indeed, early death of homozygous embryos, deleted for the following genes, resulted from defect in (i) cell proliferation (fgf4, ${ }^{4,5}$ Taube nuss, ${ }^{6} \operatorname{csn} 2,{ }^{7} \operatorname{csn} 3{ }^{8}{ }^{8}$ jab $1 / \operatorname{csn} 5^{9}$; (ii) DNA replication ( $\operatorname{cdc} 7^{10}$ ); (iii) maintenance of inner cell mass (ICM) cell pluripotency (oct4, ${ }^{11}$ foxd3,${ }^{12}$ ); (iv) cell adhesion (E-cadherin, ${ }^{13}$ maspin, ${ }^{14}$ members of laminin family ${ }^{15}$ ); (v) oxidative metabolism (thioredoxin ${ }^{16}$ ) or (vi) control of transcription (tif $\left.1 b^{17}\right)$ and translation $\left(\right.$ Traube $\left.^{18}\right)$. The links between some of these markers help for the identification of components of one specific pathway as for fgf $4 /$ oct $4,{ }^{11}$ or yet revealed cross-talks between different pathways as for oct4/thioredoxin. ${ }^{19}$ Despite these efforts, a comprehensive pattern of the overall genes regulated at these early stages of embryogenesis is still lacking.

Taking opportunity of the mouse ES cell model, we have previously shown that, 3 days upon LIF withdrawal (d3), 30\% of the mouse ES-derived differentiated cells die by apoptosis, together with activation of the $p 38 \alpha$ mitogen-activated protein kinase (MAPK) and cleavage of caspase 3 . The remaining living cells express high level of the $B C L 2$ and $B C L x / L$ proteins and thus become resistant to apoptosis. ${ }^{20}$ By studying the effects of various p38 inhibitors on ES cells upon LIF withdrawal, we found that PD169316 blocks cell apoptosis without altering the morphological differentiation process. This inhibitor increased $b c / 2$ expression and prevented procaspase 3 cleavage. The fact that it also altered the expression pattern of fgf5 and brachyury differentiation markers ${ }^{20}$ raised the possibility that a proper balance between apoptotic and survival signals might be an integrated part of cell commitment programs.

P38 MAPK family is composed of four isoforms $(\alpha, \beta, \delta, \gamma)$ each displaying various effects on cell differentiation and apoptosis. ${ }^{21,22}$ P38 activity, detected in two-cell embryos, ${ }^{23}$ is 
repressed in BMP-dependent way in pluripotent ES cells, and is reinduced upon cell differentiation. ${ }^{20,24,25}$ The physiologic nonredundant function of the $\mathrm{p} 38 \alpha$ gene in placental organogenesis and in erythropoïesis has been revealed by gene inactivation studies. ${ }^{26-28}$ Among the p38 MAPK, the p38 $\alpha$ isoform is the major phosphorylated active form present at d3 upon LIF withdrawal. ${ }^{20}$ Also, studies with different p38 inhibitors indicate that while SB203580 is a bona fide specific p38 $\alpha$ inhibitor, whose effect is close to those reported in the p38 $\alpha^{-1-}$ cell line, the PD169316 compound effects are wider, leading to survival of ES-derived early differentiated cells. ${ }^{20,29}$

In this study, we wonder whether apoptotic signals might contribute to the full expression of the differentiation programs. For this purpose, we compared gene expression profiles of ES-derived differentiated cells in which apoptosis has occurred (in the absence of PD169316) or has not (in the presence of PD169316) and characterized cell-fate regulated genes. We also demonstrated, by functional tests carried out on a subset of PD169316-regulated genes, that pluripotent ES cells may tolerate high expression of anti-apoptotic and calcium binding proteins, without losing their capacity to colonize blastocysts. In addition, we showed that overexpression of metallothionein 1 gene prevents apoptosis of early differentiated cells.

\section{Results}

\section{PD169316 induced dissociation between differentiation and apoptosis in mouse ES-derived differentiated cells}

At 3 days upon LIF withdrawal, there was a mixture of living and apoptotic differentiated cells. ${ }^{20,30}$ Our goal was to determine whether apoptotic cells contribute to the complete setting up of the differentiation programs. Since it was not convenient to separate still plated early apoptotic cell populations from lived differentiated cells, we took advantage of an apoptosis-blocking p38 inhibitor (PD169316) and compared transcriptional profiling in committed differentiated cells in which apoptosis has been inhibited (in the presence of $\mathrm{PD}$ ) or has not (in the absence of PD).

Gene profiling experiments were carried out with mRNAs prepared from two different ES cell lines (S1 and D4) grown for 3 days in cell medium with LIF (pluripotency) or without LIF in the absence (d3) or in the presence of $10 \mu \mathrm{M}$ PD169316 (d3PD). As expected from our previous work, morphological cell differentiation and apoptosis were clearly observed at d3 while, in the presence of PD, the cells underwent morphological differentiation without entering on apoptotic crisis. ${ }^{20,24}$ The percentage of apoptotic cells, as measured by flow cytometry, was about $30 \%{ }^{20}$

From the five plates prepared for each point of microarray experiments, one plate was lysed with RIPA buffer, and Western blot analyses were performed with previously defined pluripotent (STAT3) and apoptotic markers (p38 and Caspase 3). ${ }^{20,31,32}$ As expected, STAT3 was phosphorylated only in the presence of LIF in pluripotent cells and p38 phosphorylation was stimulated upon LIF withdrawal (Figure 1a and Duval et al. ${ }^{20}$ ). Also, the impairment of LIF withdrawal-induced caspase 3 cleavage and the higher

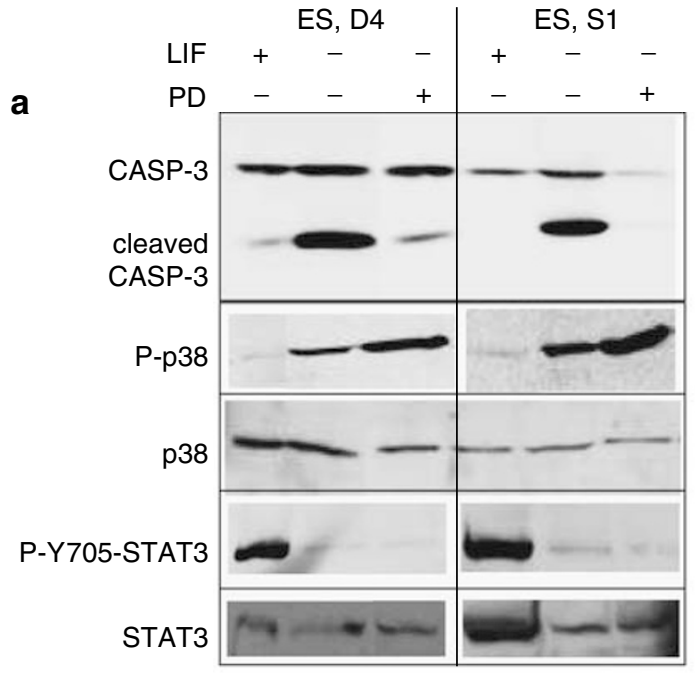

b

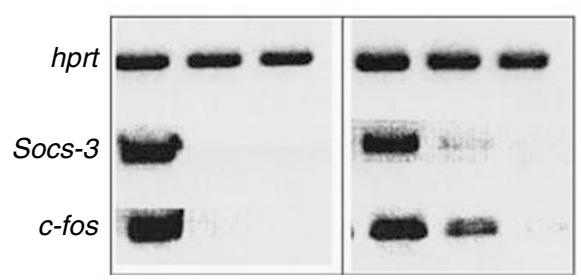

Figure 1 PD169316, a p38 inhibitor compound, impairs apoptosis in mouse ES-derived differentiated cells. (a) Protein RIPA cell extracts from D4 or S1 ES cells, grown for 3 days in the presence $(+)$ or absence of LIF $(-)$, without $(-)$ or with $10 \mu \mathrm{M}$ PD169316 $(+)$, were analyzed by Western blot with the antibodies as indicated: (caspase 3 (CASP-3), phospho-p38 (P-p38), p38 $\alpha$ (p38), phosphotyrosine 705-STAT3 (P-Y705- STAT3) and STAT3. (b) Semiquantitative RT-PCR were performed with total RNA prepared in the indicated conditions with primers corresponding to the mentioned genes: hypoxanthine guanine phosphotransferase (hprt), suppressor of cytokine signaling 3 (socs-3), c-fos

level of p38 phosphorylation, in the presence of the PD compound, indicated the proper functionality of this drug, which blocks a phosphatase-dependent p38 feedback control $^{20,33}$ (Figure 1a).

The quality of mRNAs used for microarrays profiling was checked by reverse transcribed (RT)-PCR experiments on a control (hprt) and LIF-dependent genes, socs3 and c-fos (Figure 1b).

\section{Gene profiling with or without the anti-apoptotic p38 inhibitor, PD169316}

Five independent total RNA preparations from plated ES cell lines grown for 3 days in the absence (d3) or presence of the PD169316 compound (d3PD) were set up. Total RNAs were processed and hybridized on the mouse MG_U74A and MG_U74AV2 chips (Affymetrix), which includes 10043 transcripts (Materials and Methods). Pair-wise comparisons were performed with the DMT3 and MAS5 softwares. The mean of the 'signal' for each gene in every cell growth condition was calculated. Genes quoted as 'present' or 'absent' were retrieved with the Affymetrix parameters. For each pair-wise comparison, genes quoted 'absent' in both conditions were eliminated. To identify genes differentially expressed between experimental groups, we used the 
nonparametric Wilcoxon rank sum test (or Mann-Whitney test) as detailed in Materials and Methods.

First, a comparison of gene expression profiles between pluripotent (+ LIF) and early differentiated cells at 3 days upon LIF withdrawal (d3) was completed in order to identify the set of genes induced upon LIF withdrawal, at this critical time point of irreversible differentiation cell commitment, when alive and apoptotic differentiated cells are coexisting (Table 1 in Supplementary data; from D Duval, M Trouillas , C Thibault, D Dembele and $\mathrm{H}$ Bœuf, our unpublished data). Probe sets ( $n=87$ ) corresponding to 79 genes, preferentially expressed in early differentiated cells versus pluripotent cells, were retrieved and classified by common biological properties with the NetAffx data base annotations. Differentiation markers of the three cell lineages, genes involved in the setting up of genomic imprinting, in chromatin remodeling, in cell cycle, cell architecture and in apoptotic control, as well as in various aspect of cell metabolism (including $\mathrm{Ca}^{2+}$, glucose, nucleotides and oxidative pathways) were identified (Table 1, Supplementary data).

Tables 2 and 3 (Supplementary data) depict pair-wise comparisons of genes between the d3 (differentiation and apoptosis) and d3 PD (differentiation without apoptosis). PDinduced genes $(n=96)$ belong to different families including a high proportion of genes encoding for calcium-binding proteins (as calcyclin, calgizzarin, annexin A1, A3 and A11), heavy metal binding proteins (as met1 and met2), early differentiation markers (mainly from mesoderm (muscle and bone as filamin $\beta$ and minopontin) and ectoderm (as nestin and creatine kinase)) as well as signaling, cytoskeletal and adhesion genes. Particular members of BMP/TGF $\beta$ pathways are also activated (id2, tgfbi and tgfbi4). Strikingly, genes promoting apoptosis (clusterin and perp) were also induced (Table 2, Supplementary data).

The PD-repressed genes $(n=52)$ include a key Wnt signaling pathway gene (lef1), axis determination genes of the TGF $\beta$ related family (nodal, lefty 1 and Tdgf1), apoptotic markers ( $m c / 1$ and pim2), nucleotide metabolism regulators (enpp2), and glycolysis involved genes (Table 3, Supplementary data).

The complete Affymetrix microarray data are accessible at the GEO data base web site: http://ncbi.nlm.nih.gov/projects/ geo/query/acc.cgi?accession number $=$ GSE2042.

The results obtained with the Affymetrix chips were confirmed by real-time quantitative-PCR (RTQ-PCR) on a selection of PD-regulated genes (Figure 2a). Also, direct comparison of the changes obtained by RTQ-PCR or with Affymetrix chips, plotted in Figure $2 b$, indicated that, for most of the genes, the magnitude of the Affymetrix changes were slightly underestimated when compared with those obtained using RTQ-PCR.

We have observed a good correlation of protein expression with transcript levels for two genes, bcl2 and Calcyclin, for which available antibodies were functional by Western blot analysis (Figure 2c).

\section{Functional tests with ES cell clones overexpressing some PD-regulated targets}

To get insights into the function of the genes, which were found to be modulated using microarrays, we derived stable
ES-transfectant cells expressing EGFP-fusion proteins of the genes of interest (see Materials and Methods). In a first step, we focused our attention on the PD-modulated genes highly induced by the drug as Calcyclin, Annexin A3 and Met1. The PD-repressed pim2 gene was also selected since the profile of expression of this known anti-apoptotic gene in ES cells was puzzling. ${ }^{34,35}$

ES cell clones, overexpressing EGFP-fusion proteins, were used in aggregation tests with morulas to evaluate their capacity to colonize blastocysts and to reveal potential prodifferentiation activity of the PD-regulated selected genes. ${ }^{36}$ Indeed, the property of ES cells to colonize blastocyst is rapidly lost upon ES cell differentiation, a process irreversibly committed two days upon LIF withdrawal. ${ }^{37,38}$

Fluorescent ES cell clones overexpressing, EGFP alone (control), EGFP-PD-induced fusion genes ( $b c / 2$ as a positive control; ${ }^{20}$ metallothionein 1 (met1); Annexin A3 (Ann) and calcyclin (cal)) and one EGFP- PD-repressed fusion gene (pim2), were aggregated overnight with wild-type morulas and followed for 2 days up to the formation of the blastocyst stage (Materials and Methods) (Figure 3a). Control ES cells can colonize blastocysts with a good efficiency, when grown with LIF and serum. In contrast, when they were grown for 2 days without LIF prior aggregation, they almost completely lost this property (Figure 3b). As shown in Figure 3c, none of the tested clones was impaired in its ability to colonize blastocysts, indicating that pluripotent ES cells can tolerate high expression of various EGFP-fused proteins such as the antiapoptotic proteins BCL2 and PIM2, the $\mathrm{Ca}^{2+}$-binding proteins CAL and ANN and the anti-stress protein MET1. Furthermore, this functional test revealed that none of these genes has a prodifferentiative activity on their own, when overexpressed in ES cells grown in the presence of LIF and serum.

Since these overexpressed genes neither counteracted LIF signaling nor altered the undifferentiated state of ES cells, it was of interest to analyze the effect of LIF withdrawal on these overexpressor clones. Three independent ES cell clones overexpressing EGFP alone (control), EGFP-MET1 and EGFP-BCL2 were grown in the presence $(+$ LIF) or absence of LIF for 4 days (-LIF, 4d). Protein fusion expression level was monitored with the anti-FLAG tag antibody (Figure 4a). While differentiation and apoptosis were observed with the control clone at day 4 upon LIF withdrawal, morphological differentiation with less apoptosis was observed with the clones overexpressing BCL2 or MET1 proteins (Figure 5a). In a typical experiment, as shown in Figure 4b, Caspase 3 cleavage, which is induced at the onset of apoptosis, was observed from control adherent-cell protein lysates (containing early apoptotic and living differentiated cells, Figure $4 b$, lane 2) and from control floating dying cells (Figure 4b, lane 3) as expected. However, no detectable CASP3 cleavage was observed from the plated-cell protein lysates derived from EGFP-MET1 or EGFP-BCL2 clones (Figure 4b, lanes 5 and 8), while minute amounts of cleaved CASP3 were barely detectable in the floating cell fraction for EGFP-MET1 clone (Figure 4b, lane 6). No floating cells and though no proteins were recovered from the EGFP-BCL2 clone grown for 4 days without LIF, indicating complete prevention of apoptosis (Figure 4b, lane 9). Prevention of apoptosis was slightly different in between clones. Though the 


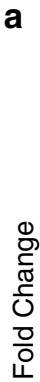

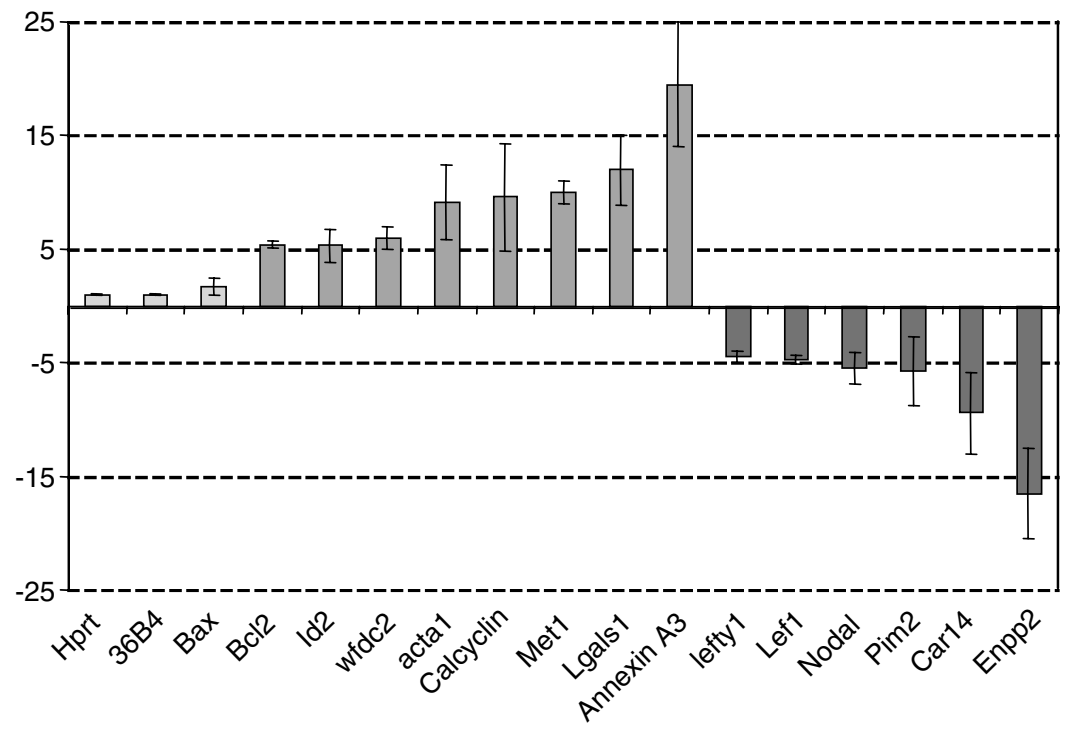

b



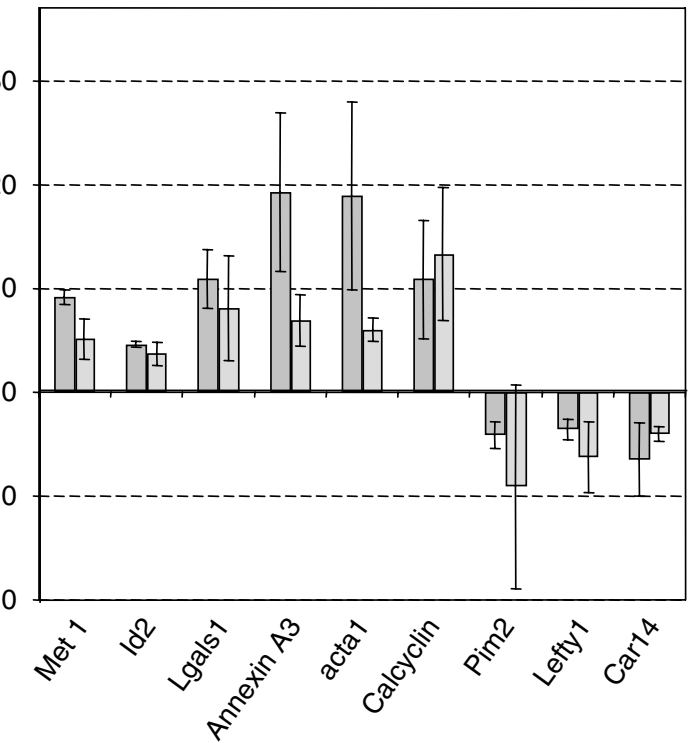

C

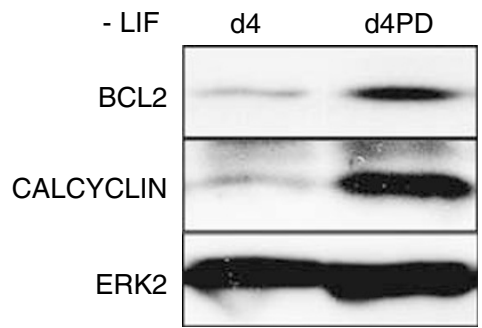

Figure 2 Validation of the microarray data on selected PD-regulated genes. (a) Total RNAs from ES cells grown without LIF for 3 days (d3), in the absence or presence of $10 \mu \mathrm{M}$ PD169316 (d3PD) were analyzed by RTQ-PCR with the corresponding specific primers. Fold change (d3PD/d3) with standard deviations (line bars) of at least four independent experiments was plotted for each gene as indicated. (b) Comparative fold change analysis, by RTQ-PCR amplification (left) or oligonucleotide microarray hybridization (right), was plotted for the indicated genes. The data represent the mean of the same triplicate microarray hybridization and RTQ-PCR amplifications. Line bars indicate standard deviation. (c) Protein RIPA cell extracts from ES cells, grown for 4 days in the absence of LIF, without (d4) or with $10 \mu \mathrm{M}$ PD169316 (d4PD), were analyzed by Western blot with the antibodies as indicated. The ERK2 antibody was used here as a control of protein loading

proportion of apoptotic cells was quantified for each clone grown without LIF and the mean values were reported (Figure 4c). In contrast, to the effect observed with BCL2 and MET1 overexpressor clones, increased expression of CAL, ANN, LGALS1 and PIM2 had no detectable effect on apoptosis (data not shown). We therefore concluded that 
a
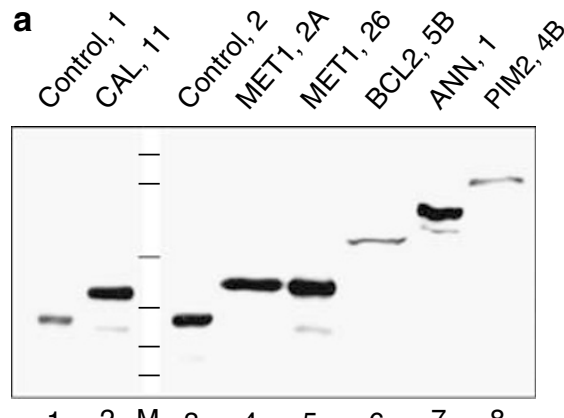

b

Number of Fluorescent ICM over total cavitated blastocysts following wt morulas/fluorescent ES cells aggregation

\begin{tabular}{ccrcc} 
& & + LIF & $\begin{array}{r}- \text { LIF } \\
\text { 24h }\end{array}$ & $\begin{array}{c}- \text { LIF } \\
\mathbf{4 8 h}\end{array}$ \\
\hline ES & Exp. 1 & $8 / 17$ & $3 / 17$ & $1 / 15$ \\
control & Exp. 2 & $19 / 25$ & $10 / 20$ & $5 / 20$ \\
& Exp. 3 & $8 / 10$ & N.D. & N.D. \\
\hline
\end{tabular}

C

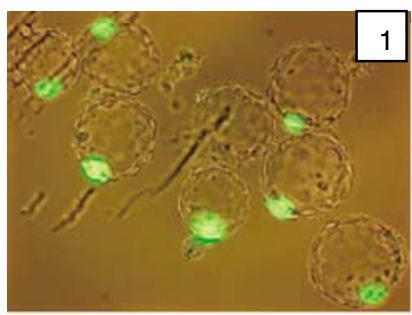

Control, 1

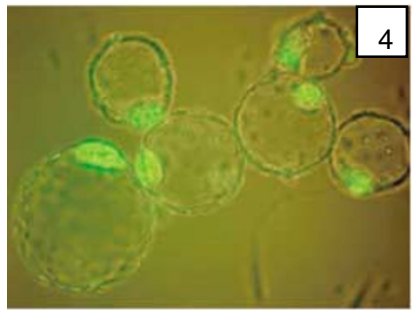

PIM2, 4B

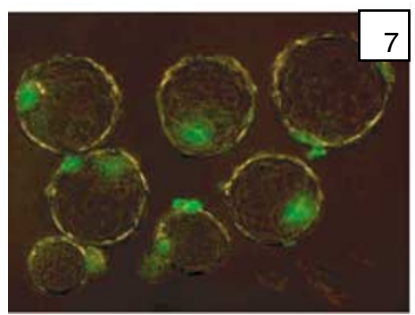

ANN, 1

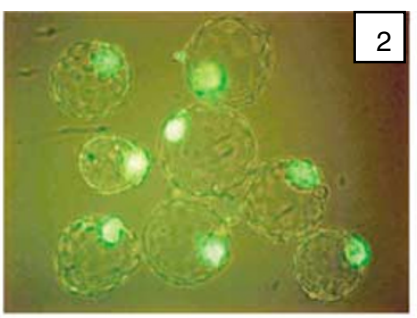

MET1, 2A

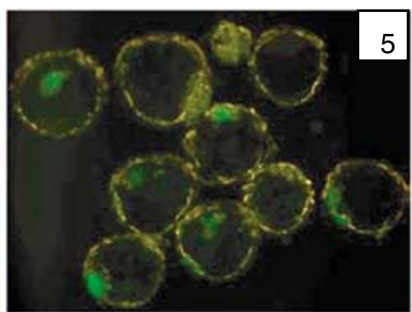

Control, 2

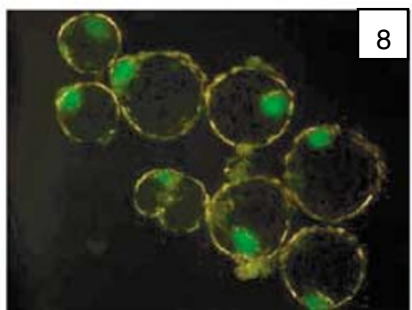

CAL, 11

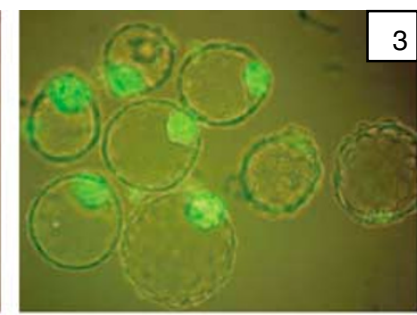

BCL2, 5B

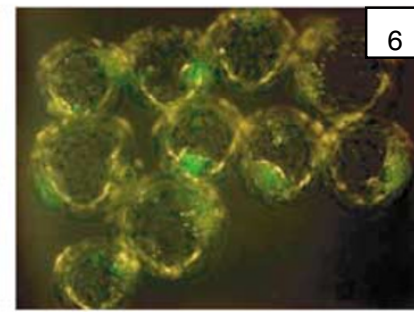

BCL2, 29

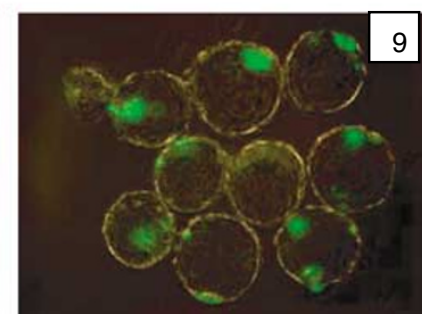

MET1, 26

Figure 3 Blastocyst colonization by fluorescent ES cell clones overexpressing a subset of PD-regulated genes. (a) Western blot analysis with the anti-EGFP antibody of RIPA cell extracts from the indicated clones overexpressing the EGFP protein alone (control 1 and 2 (two independent clones)), or the EGFP-CALCYCLIN (CAL, clone 11), EGFP-MET1 (clones 2A and 26), EGFP-BCL2 (clone 5B), EGFP-ANNEXIN A3 (ANN, clone1) and EGFP-PIM2 (clone 4B). M: protein molecular weight marker. (b) The table represents the efficiency of fluorescent ES cells to colonize inner cell mass of blastocyst, when grown with LIF or in the absence of LIF for 24 or $48 \mathrm{~h}$. (c) Blastocysts with the fluorescent ICM derived after overnight cell aggregation between wild type (non-fluorescent) eight-cell morulas and fluorescent ES cell clones overexpressing the proteins as mentioned in (a). Clones have been made in different ES cell lines: 1, 2, 3 and 4: S1 ES cell line and 5, 6, 7, 8, 9, CGR8 ES cell line. Enlargement is 200 -fold

BCL2 and MET1 protect ES-derived precursor cells from apoptosis, and that BCL2 has a more potent effect than MET1.

To determine whether BCL2 or MET1, which impair apoptosis, were putative mediators of PD which might affect lineage specification, we have grown WT and overexpressor clones for a week without LIF. No striking morphological differences were observed with the various clones, which differentiate in heterogeneous cell population (Figure 5a). In addition, immunolabelling of differentiated cells with NESTIN (Figure 5a), and Western blot analysis with BRACHYURY (Figure 5b), two PD-regulated genes, were performed with
WT and overexpressor clones grown for 7 days without LIF. Protein expression of these two markers was not altered. This indicates that although overexpression of met 1 or $b c / 2$ prevents apoptosis, these two genes do not mimick the effect of $P D$ regarding expression of nestin or brachyury differentiation markers.

\section{Discussion}

The understanding of genetic programs involved in the maintenance of ES cell pluripotency as well as those 


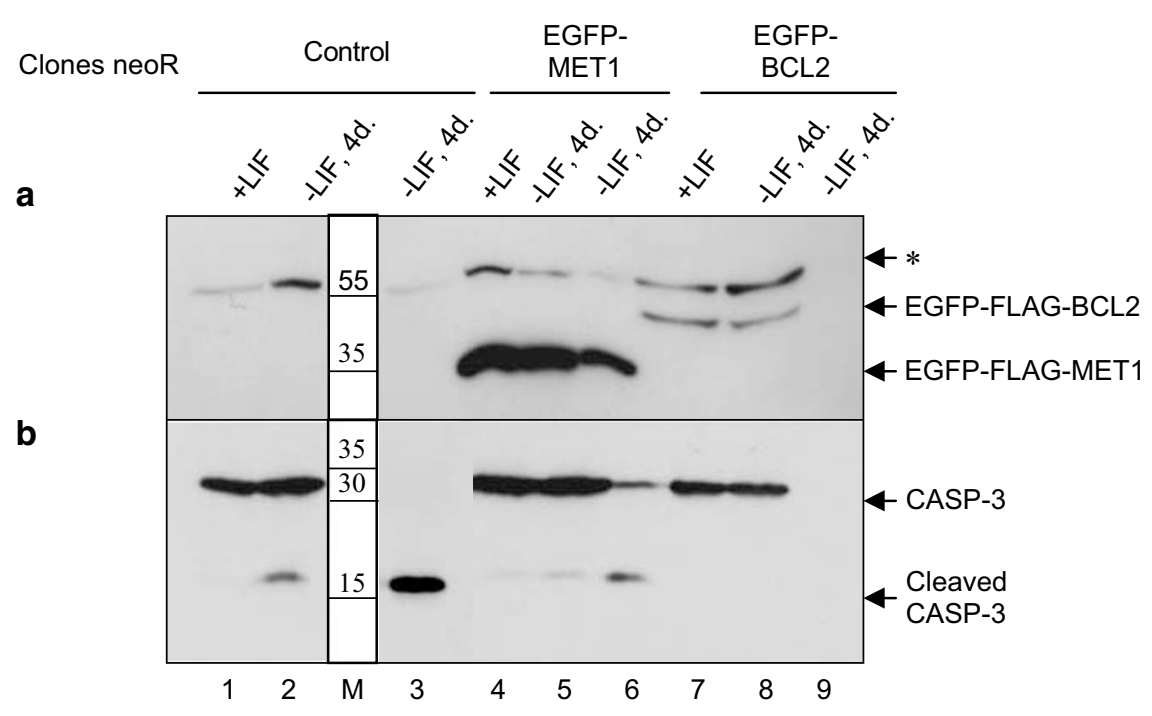

C

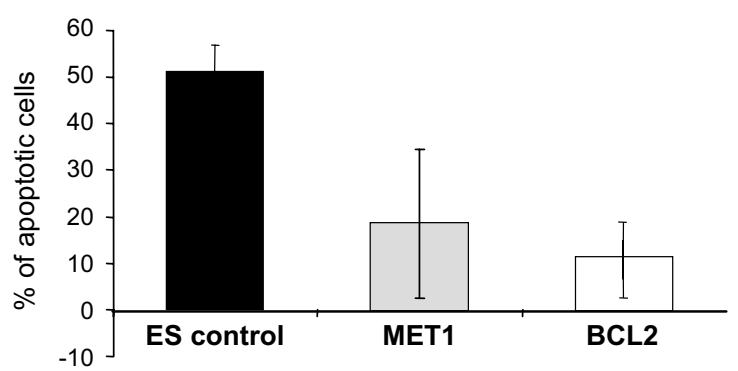

Figure 4 Overexpression of BCL2 and MET1 prevents LIF-withdrawal induced cell apoptosis. Protein RIPA cell extracts from ES cell clones overexpressing EGFP alone (control), EGFP-MET1 or EGFP-BCL2, grown in the presence or absence of LIF for 4 days (d) as indicated, were analyzed by Western blot with the anti-FLAG (a) or anti-Caspase 3 (CASP-3) (b) antibodies. Asterisk points to an unspecific band revealed with the anti-FLAG antibody. Lanes 1, 2, 4, 5, 7, and 8 correspond to protein extracts from the plated cells (living and early apoptotic cells). Lanes 3, 6 and 9 are protein cell extracts from the floating dying apoptotic cells. This cell fraction was completely absent in lane 9 (no signal) (c) \% of apoptotic cells measured at 4 days upon LIF withdrawal: the mean of ratio of cleaved caspase 3 versus total caspase 3 signals, with standard deviation, was plotted for the ES WT (control), EGFP-MET1 and EGFP-BCL2 overexpressors as indicated. These values are from four experiments performed with two independent overexpressor clones

modulated upon differentiation commitment is essential for manipulation of these cells for future medical use via cellular therapy strategies. Identification and function of genes whose expression is modulated upon the first steps of embryogenesis remain largely unknown despite current efforts to characterize such genes with preimplantation embryo cultures or gene targeted model mice. Pioneering works, however, indicated that regulation of apoptotic pathways was of critical importance for proper embryo development starting at the blastocyst stage. ${ }^{2,39}$

To study the links between apoptosis and differentiation, we have taken advantage of a p38 MAPK inhibitor (PD169316), which prevents apoptosis of ES-derived differentiated cells obtained at 3 days upon LIF withdrawal. By comparing gene expression profiles of ES-derived differentiated cells grown in the absence or in the presence of this inhibitor, we have identified key gene families whose transcriptional regulation was correlated with cell fates (differentiation and apoptosis or differentiation without apoptosis). On purpose, we have been using different ES cell lines (D4, growing on feeder cells) and $\mathrm{S} 1$ (feeder cells free) to get a better 'universal' list of genes depending on cell fates rather than on particular properties of each cell line.

\section{Specialized cell markers are present at d3}

Among the genes expressed under differentiation and apoptosis conditions, there are members of the Wnt pathway (frzl2, sfrzl2 and pitx2), required for embryo patterning at the critical gastrulation step, ${ }^{40-42}$ and genes previously identified as specific markers of lineages: sox11 involved in neural and pancreatic differentiation; ${ }^{43}$ hes 6 , a Notch target implied in neurogenesis and myogenesis, myosin light 9 , involved in muscle contraction and utp14a, a small ribonucleoprotein essential during spermatogenesis. ${ }^{44}$ We identified also a marker of neuroepithelial and hematopoetic stem cells (prominin1), ${ }^{45}$ and synthaxin3, needed for neurotransmitter transport. This pattern of gene transcription strongly suggested that at d3 there is, as expected, a mixture of various differentiated cell types, which expressed, much earlier than anticipated, specialized cell markers.

Critical cell cycle genes, which regulate the G1/S transition, are also induced at d3: cdki p57, mapk12, myb and L-myc1. These genes may be involved in the setting up of the $\mathrm{G} 1$ checkpoint, almost absent in undifferentiated ES cells and induced upon their differentiation. ${ }^{46-48}$ Also, worth to be mentioned among the genes induced upon LIF withdrawal are genes involved in chromatin remodelling (cbx2, Carm1 and 
a
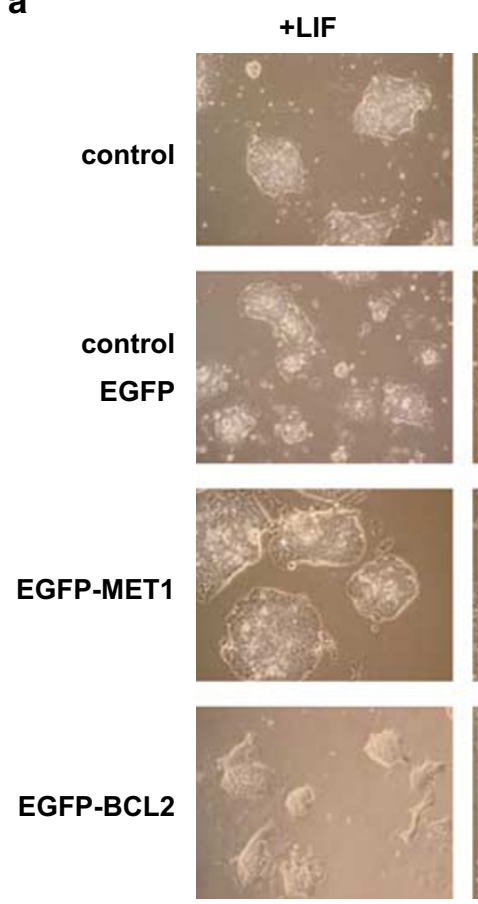

b
-LIF 7 days
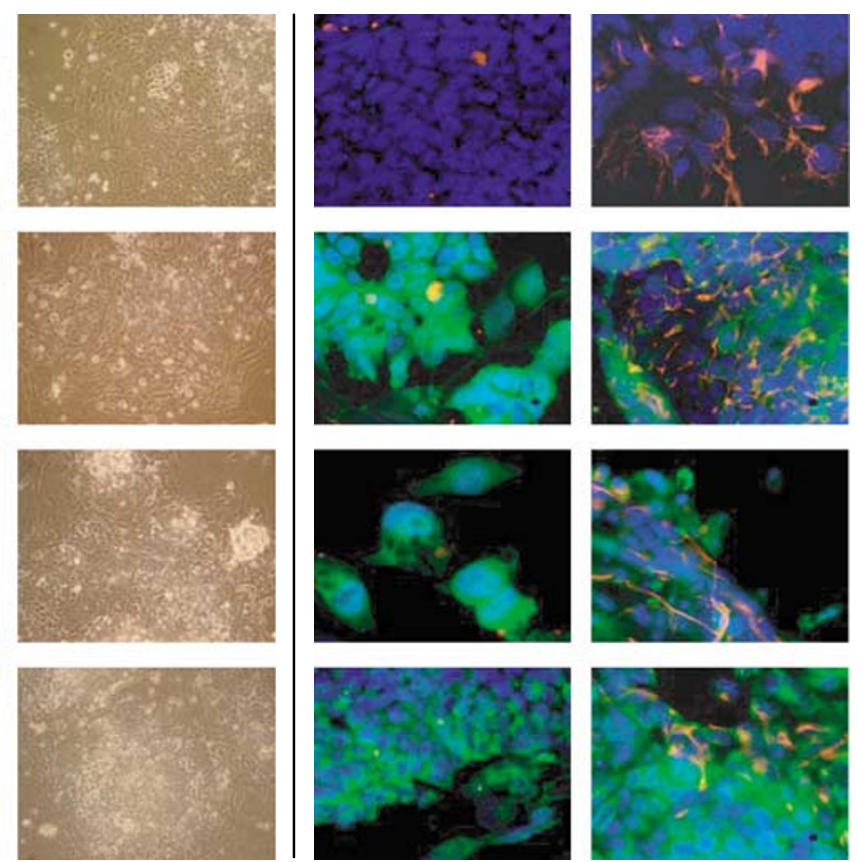

Isotypic

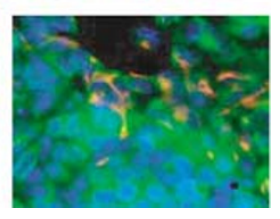

Nestin

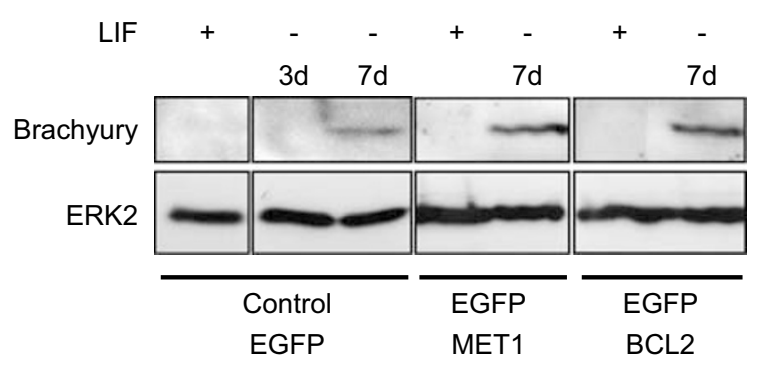

Figure 5 Overexpression of BCL2 or MET1 does not impede global heterogeneous differentiation triggered upon LIF withdrawal. (a) Phase contrast pictures (enlargement $\times 100$ ) and immunolabelling of ES cells (control) or clones overexpressing EGFP alone (control EGFP), EGFP-MET1 or EGFP-BCL2, grown in the presence (+ LIF) or in the absence of LIF for a week (d7). Differentiated cells were immunolabelled with an isotypic or the specific antinestin antibodies as indicated. Merged pictures showing EGFP (green), Dapi staining (blue) and isotypic or NESTIN proteins (red) are presented (enlargement $\times 600$ ). (b) Western blot analysis, with the anti-Brachyury antibody, of RIPA cell extracts from the indicated clones as defined in (a), grown in the presence $(+)$ or absence of LIF for 3 days (d3) or 7 days (d7) as indicated

Sox3), ${ }^{49}$ in cell adhesion [embigin, ${ }^{50}$ jam3, fibulin- $1^{51}$ ], in G-protein linked signaling (arrestin b1) and in apoptotic/cell growth regulation (pim2). Eventually, we have identified genes involved in stress responses (peroxiredoxin 6, glutathione-S transferase, ${ }^{52}$ in DNA repair process (Ercc5), and in glucose (glycolysis enzymes), protein and nucleic acid metabolism.

\section{PD regulates cell stresses}

Our microarray analyses revealed that the anti-apoptotic PD compound, known to induce the expression of $b c / 2$ and $b c / x L$, has an impact on gene families controling stresses $\left(\mathrm{Ca}^{2+}\right.$-binding proteins, as calcyclin and Annexin, detoxifying proteins as metallothionein), cell shape (cytoskeletal and adhesion proteins) and cell cycle/proliferation (gadd45a and septin4). This suggests that (i) $\mathrm{Ca}^{2+}$ buffering, by increased expression of at least $13 \mathrm{Ca}^{2+}$-binding proteins is of importance, potentially to block apoptosis at $\mathrm{d} 3$, and that (ii) differentiation process has started together with changes in cell morphology and setting up of DNA damage control. As BCL2 regulates the communication between reticulum endoplasmic and mitochondrion by $\mathrm{BH} 3-$ only proteins and calcium ions, ${ }^{53}$ it is possible that PD-induced expression of BCL2 would help a passive release of $\mathrm{Ca}^{2+}$ from the reticulum endoplasmic, ${ }^{54}$ which is buffered by $\mathrm{Ca}^{2+}$-binding proteins, resulting to prevention of mitochondrial damage and apoptosis.

Functional tests revealed the importance of BCL2 and MET1 to impair apoptosis of early differentiated cells (Duval et al. ${ }^{20}$ and this work). Though, MET1, which was previously known to suppress doxorubicin-induced apoptosis, 55,56 appeared to play a role in early precursor cells. We have not yet identified the critical $\mathrm{Ca}^{2+}$-binding proteins potentially 
involved in the PD-dependent anti-apoptotic effect since none of the $\mathrm{Ca}^{2+}$-binding proteins, overexpressed alone (as CAL and ANN), prevented LIF withdrawal-induced apoptosis.

We demonstrated that ES cell clones grown in the presence of serum and LIF and overexpressing different EGFP-fused proteins did not loose their capacity to colonize blastocysts. This indicated that none of these genes display prodifferentiative capacity on their own. In addition, the test revealed that $E S$ cells may tolerate high level of anti-apoptotic (as MET1, BCL2 or PIM2) or $\mathrm{Ca}^{2+}$-binding proteins (as CAL and $A N N$ ) without consequences, suggesting that it could be used in large screening experiments to identify blastocystcolonizing perturbing genes.

\section{Apoptosis and cell differentiation: PD regulates cell lineage commitment}

We had previously shown that PD represses expression of Brachyury and fgf5 differentiation markers. ${ }^{20}$ These microarray analyses revealed PD-dependent repression of (i) lef1, a Wnt pathway-induced transcription factor required for the maintenance of Brachyury expression during gastrulation ${ }^{57}$ and of (ii) axis symmetry regulating genes of a TGF $\beta$-related pathway (nodal; Tdgf1 and lefty1 genes). ${ }^{58,59}$ Repression of brachyury and nodal-dependent pathways, which are both involved in mesendoderm differentiation ${ }^{60}$ may explain why, despite nestin, recently identified as a multilineage marker, ${ }^{61,62}$ we could not identify, in this study performed on the equivalent of the third of the mouse transcriptome, any 'endodermal' quoted genes. This result is statistically worth to be mentioned even if we cannot rule out that endodermal lineage's genes might be identified after complete mouse transcriptome analysis. In contrast, PD also induces a subset of mesodermal lineage genes known to be critical for chondrocyte, osteoblast and myoblast differentiation as filamin $B,^{63}$ calcyclin $^{64,65}$ and the sparc/osteonectin. ${ }^{66,67}$ Altogether, these data suggest that at least two mesodermcommitment programs are coexisting: a Wnt/lef1/brachyurydependent and a brachyury-independent programs, respectively repressed or induced when apoptosis is blocked.

Our study also revealed that overexpression of BCL2 or MET1, which impaired apoptosis between day 3 to day 5 upon LIF withdrawal, did not alter heterogeneous cell differentiation triggered upon simple LIF withdrawal. Specific differentiation procedures leading to particular cell lineages, performed in the presence of PD or with each of these overexpressors, should allow to determine more precisely the importance of apoptosis for cell-fate commitment.

In conclusion, we have set up a strategy to characterize cell-fate regulated genes by using a p38 inhibitor during differentiation processes triggered upon LIF withdrawal in ES cells. In addition, we have demonstrated the usefulness of functional tests performed with EGFP-labelled overexpressor ES cells to study genes identified by microarray analyses. Our study led to the identification of markers expressed at early stages of differentiation and shows that blocking apoptosis leads to an alteration of calcium, cell stress, adhesion, and glucose metabolism along with a modulation in the expression of key differentiation commitment genes.
Future experiments with these identified gene families should improve our knowledge of the links between apoptosis and cell differentiation.

\section{Materials and Methods}

\section{Cell culture and reagents}

S1, CGR8 (feeder free) and D4 (a D3 subclone, ${ }^{68}$ feeder-dependent) ES cell lines (from 129SV mouse) were derived as described ${ }^{69}$ and grown in DMEM, high glucose (Invitrogen Corporation), supplemented with $0.1 \mathrm{mM}$ $\beta 2$ Mercaptoethanol, 10\% FCS, $400 \mathrm{ng} / \mathrm{ml}$ gentamycin and LIF (500 pM). All experiments were performed with plated pluripotent (+ LIF) or differentiated cells obtained after 3 days (d3), 4 days (d4) or 7 days (d7) of growth without LIF.

For microarray experiments, plated ES cells (after two passages without feeders for D4 cell line), were diluted at $10^{5} \mathrm{cells} / \mathrm{ml}$ in ES cell medium with or without LIF in the presence or absence of $10 \mu \mathrm{M}$ PD169316. Cell medium was changed every day and cells were lysed after 3 days of treatment.

The anti-STAT3 (F-2), anti-p38 (N-20), anti-calcyclin (E-20), anti-Bcl2 $(\mathrm{N}-19)$ and anti-Brachyury ( $\mathrm{N}-19)$ (Santa Cruz Biotechnology), antiphospho-Tyr 705 STAT3, anti-phospho-p38 and anti-Caspase3, (Cell signaling Technology), anti-Flag (UBI Company, 2EL-1B11 mouse monoclonal), anti-EGFP (BD company, JL-8 mouse monoclonal), antiNestin (Chemicon), Alexa fluor 594 goat anti-mouse IgG (Molecular probes) and isotypic mouse IgG2A (Sigma) antibodies were used as recommended by the manufacturer. The PD169316, diluted in DMSO, was from Calbiochem. Dapi was from Sigma. Fluorescent mounting medium was from Dakocytomation.

\section{Differentiation procedure and apoptotic test}

ES cells were plated at low cell density $\left(5 \times 10^{5}\right.$ cells $\left./ \mathrm{ml}\right)$ in LIF-containing medium. The day after, plated cells were washed with PBS and fed for the indicated times ( 3,4 or 7 days) with medium supplemented or not with LIF. Medium was changed every day. Apoptosis was detected by Western blot analysis with anti-Caspase 3 antibody, which reveals the full length or cleaved activated form of Caspase 3 proteins. The $\%$ of apoptotic cells was determined as the ratio of cleaved Caspase 3 versus total caspase 3 signals (cleaved and not cleaved), at 4 days without LIF, after scanning of the different specific bands, revealed by Western blot. For each independent experiment, background level of apoptosis, detected for cells grown with LIF, was removed.

\section{Cell lysates, Western blots and immunohistochemistry}

Plated cells were rinsed twice with room temperature PBS and lysed directly in mild RIPA buffer (PBS, $1 \%$ triton, 1\% NP40, 0.05\% SDS, $1 \mathrm{ng} / \mathrm{ml}$ protease inhibitor cocktail, $1 \mathrm{mM}$ Pefabloc, $20 \mathrm{mM} \mathrm{NaF}, 1 \mathrm{mM} \mathrm{Na}$ vanadate) and centrifuged $10 \mathrm{~min}$ at 10000 r.p.m. When mentioned, apoptotic cells were recovered with cell medium, centrifuged for $2 \mathrm{~min}$ at 2000 r.p.m. and the pellet was lysed in mild RIPA buffer as above. Cell lysates were resolved by SDS-PAGE (10 or $12 \%$ (for Caspase 3 )) and electro-transferred onto nitrocellulose membranes in the presence or absence (for Caspase 3) of $0.07 \%$ SDS. Proteins were reacted with the different antibodies, as recommended by the manufacturers.

Immunolabelling of cells with antinestin or isotypic antibodies were carried out as described ${ }^{70}$ with minor modifications: Cells were fixed with 
$4 \%$ formaldehyde in PBS for $10 \mathrm{~min}$ at room temperature and permeabilized with $0.1 \%$ Triton $\mathrm{X}-100$ for $20 \mathrm{~min}$. Fixed cells were rinsed with PBS and incubated with blocking buffer (PBS, 3\% bovine serum albumin (BSA), $0.1 \%$ Triton $\mathrm{X}-100$ ) for $1 \mathrm{~h}$, followed by incubation with the primary antibody (antinestin diluted $1 / 300$, isotypic antibody diluted $1 / 100$ ), at room temperature for $1 \mathrm{~h}$ in PBS with $0.5 \% \mathrm{BSA}$ and $0.1 \%$ Triton X-100. After washing with PBS, cells were incubated for $1 \mathrm{~h}$ with species-specific fluorescence-labeled secondary antibodies diluted 1/6000. Samples were washed twice with PBS, counterstained with Dapi at $100 \mathrm{ng} / \mathrm{ml}$ for $2 \mathrm{~min}$ and observed under mounting medium. Immunofluorescent pictures (enlargement $\times 600$ ) were recorded by computer acquisition using the quips smart capture visys software with the Olympus AX70 microscope.

\section{Semiquantitative RT-PCR and RTQ-PCR}

Total RNAs from adherent ES cells were prepared with the Qiagen column kit (Qiagen) and treated with DNAse (5U/100 ng RNA, Sigma). Total RNA $(5 \mu \mathrm{g})$ was RT with random hexameric primers and the MLV Reverse Transcriptase (Sigma). The RT reaction products were used for PCR reactions with specific primer sets as previously described. $^{24}$

RTQ-PCR experiments have been performed with the Light Cycler system (Roche, Idaho Technologies) as described. ${ }^{20}$ The $\mathrm{Cp}$ value (minimum cell cycle number in the linear zone of amplification) was determined for each gene in these conditions: 3 days without LIF (d3) or 3 days without LIF $+10 \mu \mathrm{M}$ PD169316 (d3PD). The FC (fold change), corresponding to the level of induction or repression of gene expression in the presence of PD169316 was calculated with this formula: $2^{(\mathrm{Cp}(\mathrm{d} 3)-\mathrm{Cp}(\mathrm{d} 3 \mathrm{PD}))}$.

The primers used for hprt, Socs-3 and c-fos have been described. ${ }^{24}$ Sequences of primers used for all the genes tested in RT-PCR or RTQPCR are as follows:

acta1/actin alpha1

5' CGT GTT GGA TTC TGG GGA CGG TGT CAC CCA C

5' CAT GAT GCT GTT GTA GGT GGT CTC ATG GAT CC

Annexin $A 3$

5' AGA GGA CTT GGG ACT GAC GA

5' TCA GGG CAT CTT CAT CTG TG

Wfdc2

5' AGG TGG ACA GCC AGT GTT CT

$5^{\prime}$ GGA CCA GGA AGA AAT GCA AA

Bax

5' TGC AGA GGA TGA TTG CTG AC

5' GGA GGA AGT CCA GTG TCC AG

$B c / 2$

5' GGT GGT GGA GGA ACT CTT CA

$5^{\prime}$ ACC TAC CCA GCC TCC GTT AT

Lgals1/Lectin

5' TCT CAA ACC TGG GGA ATG TC

5 ' CTG GTC AAA GGT GAT GCA CA

Car14/CAXIV

5' CCC ATG GAT ATG ACC AGC TT

5' TGG CTT CAC TGT TGA TCT GG

Calcyclin

5' CCT TCT CGT GGC CAT CTT C

5' AAG GCG ACA TAC TCC TGG AA

Lefty $1 /$ Ebaf

5' CAG TCC TGG ACA AGG CTG AT

5' GCT CCA TTC CGA ACA CTA GC

\author{
Enpp2 \\ 5' TCG CTC TCA TAT GTA TGC AGG T \\ 5' TGT GAT GGT CCT CTC TCT GTG T \\ Hprt \\ $5^{\prime}$ TGC TCG AGA TGT CAT GAA GG \\ $5^{\prime}$ TAT GTC CCC CGT TGA CTG AT \\ Id2 \\ $5^{\prime}$ ATC CCC CAG AAC AAG AAG GT \\ 5' ATT CAG ATG CCT GCA AGG AC \\ Lef1 \\ 5' AAG AAA TGA GAG CGA ATG TCG T \\ 5' TTC TGG GAC CTG TAC CTG AAG T \\ Met1 \\ $5^{\prime}$ ATG GAC CCC AAC TGC TCC T \\ 5' GCG CCT TTG CAG ACA CAG \\ Nodal \\ 5' CCA AGA AGA GGA TCT GGT ATG G \\ 5 ' GAGTAGAGCATGAGCACATTGG \\ Pim2 \\ 5' ACATGGTCTGTGGGGACATT \\ $5^{\prime}$ TTGATGGGCTTTTCTTCAGC \\ $36 \mathrm{~B} 4$ \\ $5^{\prime}$ ATGTGAAGTCACTGTGCCAG \\ $5^{\prime}$ GTGTAATCCGTCTCCACAGA.
}

\section{Microarray experiments: hybridization and data analysis}

Total RNAs from adherent ES cells were prepared with the Qiagen column kit (Qiagen) and treated with DNAse (5U/100 ng RNA, Sigma). Biotinylated cRNAs were prepared according to the standard Affymetrix protocol (Expression Analysis Technical Manual, 1999; Affymetrix). In brief, double-stranded cDNA was synthesized from $5 \mu \mathrm{g}$ total RNA using the SuperScript Choice System from InVitrogen and the Affymetrix T7(dT) 4 primer, which contains a T7 RNA polymerase promoter attached to a poly-dT sequence. Following phenol/chloroform extraction and ethanol precipitation, the CDNAs were transcribed into biotin-labeled cRNAs using the BioArray High Yield RNA Transcript labeling kit (ENZO Diagnotics, Farmingdale, NY, USA). The cRNAs produced were purified using RNeasy kit (Qiagen) and fragmented to an average size of 30-50 bases according to Affymetrix recommendations. Fragmented cRNAs $(10 \mu \mathrm{g})$ were hybridized for $16 \mathrm{~h}$ at $45^{\circ} \mathrm{C}$ on murine MG_U74 GeneChips (MG_U74A and MG_U74Av2). These arrays interrogate $~ 10043$ probe sets, including all $(\sim 5000)$ functionally characterized sequences in Mouse Unigene database and $\sim 5000$ EST clusters. GeneChips were washed and stained in the Affymetrix Fluidics Station 400 and further scanned using the Hewlett-Packard GeneArray Scanner G2500A. The image data were analyzed with Microarray Suite version 5.0 (MAS5) using Affymetrix default analysis settings and global scaling as normalization method. The trimmed mean target intensity of each chip was arbitrarily set to 100 . Absolute analysis generate a 'signal' value (expression level) for each probe set and a detection call of 'absent', 'present' or 'marginal'. ${ }^{71,72}$ As experiments were performed at different times, we further normalized the data using the quantile method. ${ }^{73}$ To identify differentially expressed genes between experimental groups, we used the nonparametric Wilcoxon rank sum test (or Mann-Whitney test). For controlling the false discovery rate due to multiple comparisons, a bootstrap analysis was carried out. ${ }^{74} \mathrm{~A}$ random perturbation test of 10000 combinations was carried out for each gene without replacing any value. Differentially 
expressed genes were selected based on the Wilcoxon $P$-value, the Affymetrix detection call and differences in 'signal' intensity between groups.

\section{Construction of expression vectors}

pCXN2-EGFP-BCL2 vector has been previously described. ${ }^{20}$ The vectors encoding the EGFP-MET1 (Metallothionein1), EGFP-CAL (Calcyclin), EGFP-PIM2 and EGFP-ANN (Annexin A3) fusion proteins have been constructed as follows: RT-PCR amplified fragments (made from d3PD treated cells) of each c-DNA of interest were cloned first in the p513kEGFP-Flag. ${ }^{20}$ The blunted (kEGFP-flag-c-DNA of interest) fragment was then recloned in blunted Xhol site of the PCXN2 vector, which includes a TK-neo selection cassette (vector previously called pCAGGS-neo ${ }^{75}$ ). All constructs, but not ANN, contained a tag-FLAG sequence in front of the $c$-DNA of interest.

\section{Stable ES clones expressing EGFP fusion proteins}

To establish ES cell clones expressing the different EGFP fusion proteins, CGR8 or S1 ES cells, maintained in LIF-containing medium, were transfected with $6 \mu \mathrm{g} / 9 \mathrm{~cm}$ Petri dishes of the different pCXN2-derived vectors with Exgen 500 (Euromedex). Clones were also derived expressing the EGFP protein alone (control). After 2 weeks of selection in the presence of $300 \mu \mathrm{g} / \mathrm{ml}$ of G418, EGFP/G418 double-positive clones were recovered and grown in the constant presence of G418. Experiments were performed on homogeneous fluorescent clones (as determined by flow cytometry, data not shown) and protein expression levels were monitored with the anti-Flag or anti-EGFP antibodies.

\section{Aggregation experiments of fluorescent ES cell clones with morulas}

Aggregation of fluorescent ES clones, overexpressing PD regulated genes, with CD1 mice morulas $(2.5 \mathrm{dpc})$ were carried out as described. ${ }^{76}$ Briefly, around 20 fluorescent ES cells were aggregated with one eight-cell morula overnight in a drop of KSOM medium under oil. A measure of 10-20 drops of independent aggregations was performed per point in each experiment. Fluorescence of the ICM of the resulting blastocysts was recorded $24 \mathrm{~h}$ after aggregation with a Leica DM IRB microscope connected to a cool snap photometric camera. Magnification is $\times 200$. Similar results were obtained with the S1, D4 and CGR8 ES cell lines.

\section{Acknowledgements}

We thank R Kemler, for the gift of the D3 ES cell line, A Smith and C Dani for the gift of the CGR8 cell line, F Rufenach, I Colas and E Troesch, from the oligonucleotide facility service at IGBMC, for the synthesis of the primers used in this work, Dr. Miyazaki for the PCNX2 expression vector and $D$ Metzger, M Okabe and M Vigneron for the gift of EGFP expressing vectors. We thank $X$ Gauthereau for $E S$ cell culture expertise, all members of the UMR-5164-CNRS-CIRID for fruitful discussions and Jean François Moreau and Pierre Dubus for careful reading of the manuscript. HB thanks $C$ Kedinger for supports and good advices concerning starting points of this project. This work was founded by CNRS, The CHU Bordeaux, University of Bordeaux 2, Region Aquitaine, the ARC and Ligue National contre le cancer, comité de Gironde, the Ministere of research (Affymetrix microarray grant, IGBMC genopole platform, Strasbourg). Marina Trouillas was a recipient of a University Bordeaux 2, assistant fellowship.

\section{References}

1. Joza N, Susin SA, Daugas E, Stanford WL, Cho SK, Li CY, Sasaki T, Elia AJ, Cheng HY, Ravagnan L, Ferri KF, Zamzami N, Wakeham A, Hakem R, Yoshida H, Kong YY, Mak TW, Zuniga-Pflucker JC, Kroemer G and Penninger JM (2001) Essential role of the mitochondrial apoptosis-inducing factor in programmed cell death. Nature 410: 549-554

2. Coucouvanis $E$ and Martin GR (1999) BMP signaling plays a role in visceral endoderm differentiation and cavitation in the early mouse embryo. Development 126: 535-546

3. Brison DR and Schultz RM (1998) Increased incidence of apoptosis in transforming growth factor alpha-deficient mouse blastocysts. Biol. Reprod. 59: $136-144$

4. Feldman B, Poueymirou W, Papaioannou VE, DeChiara TM and Goldfarb M (1995) Requirement of FGF-4 for postimplantation mouse development. Science 267: 246-249

5. Goldin SN and Papaioannou VE (2003) Paracrine action of FGF4 during periimplantation development maintains trophectoderm and primitive endoderm. Genesis 36: 40-47

6. Voss AK, Thomas T, Petrou P, Anastassiadis K, Scholer H and Gruss P (2000) Taube nuss is a novel gene essential for the survival of pluripotent cells of early mouse embryos. Development 127: 5449-5461

7. Lykke-Andersen K, Schaefer L, Menon S, Deng XW, Miller JB and Wei N (2003) Disruption of the COP9 signalosome Csn2 subunit in mice causes deficient cell proliferation, accumulation of p53 and cyclin E, and early embryonic death. Mol. Cell. Biol. 23: 6790-6797

8. Yan J, Walz K, Nakamura H, Carattini-Rivera S, Zhao Q, Vogel H, Wei N, Justice MJ, Bradley A and Lupski JR (2003) COP9 signalosome subunit 3 is essential for maintenance of cell proliferation in the mouse embryonic epiblast. Mol. Cell. Biol. 23: 6798-6808

9. Tomoda K, Yoneda-Kato N, Fukumoto A, Yamanaka S and Kato JY (2004) Multiple functions of Jab1 are required for early embryonic development and growth potential in mice. J. Biol. Chem. 279: 43013-43018

10. Kim JM and Masai H (2004) Genetic dissection of mammalian Cdc7 kinase: cell cycle and developmental roles. Cell Cycle 3: 300-304

11. Nichols J, Zevnik B, Anastassiadis K, Niwa H, Klewe-Nebenius D, Chambers I, Scholer $\mathrm{H}$ and Smith A (1998) Formation of pluripotent stem cells in the mammalian embryo depends on the POU transcription factor Oct4. Cell 95: 379-391

12. Hanna LA, Foreman RK, Tarasenko IA, Kessler DS and Labosky PA (2002) Requirement for Foxd3 in maintaining pluripotent cells of the early mouse embryo. Genes Dev. 16: 2650-2661

13. Riethmacher D, Brinkmann V and Birchmeier C (1995) A targeted mutation in the mouse E-cadherin gene results in defective preimplantation development. Proc. Natl. Acad. Sci. USA 92: 855-859

14. Gao F, Shi HY, Daughty C, Cella N and Zhang M (2004) Maspin plays an essential role in early embryonic development. Development 131: 1479-1489

15. Miner JH, Li C, Mudd JL, Go G and Sutherland AE (2004) Compositional and structural requirements for laminin and basement membranes during mouse embryo implantation and gastrulation. Development 131: 2247-2256

16. Matsui M, Oshima M, Oshima H, Takaku K, Maruyama T, Yodoi J and Taketo MM (1996) Early embryonic lethality caused by targeted disruption of the mouse thioredoxin gene. Dev. Biol. 178: 179-185

17. Cammas F, Mark M, Dolle P, Dierich A, Chambon P and Losson R (2000) Mice lacking the transcriptional corepressor TIF1beta are defective in early postimplantation development. Development 127: 2955-2963

18. Thomas T, Voss AK, Petrou $P$ and Gruss $P(2000)$ The murine gene, Traube, is essential for the growth of preimplantation embryos. Dev. Biol. 227: 324-342

19. Guo Y, Einhorn L, Kelley M, Hirota K, Yodoi J, Reinbold R, Scholer H, Ramsey $\mathrm{H}$ and Hromas R (2004) Redox regulation of the embryonic stem cell transcription factor oct-4 by thioredoxin. Stem Cells 22: 259-264

20. Duval D, Malaise M, Reinhardt B, Kedinger C and Boeuf H (2004) A p38 inhibitor allows to dissociate differentiation and apoptotic processes triggered upon LIF withdrawal in mouse embryonic stem cells. Cell Death Differ. 11: 331-341

21. Cross TG, Scheel-Toellner D, Henriquez NV, Deacon E, Salmon M and Lord JM (2000) Serine/threonine protein kinases and apoptosis. Exp. Cell Res. 256: 34-41 
22. Baeza-Raja B and Munoz-Canoves P (2004) p38 MAPK-induced nuclear factor-kappaB activity is required for skeletal muscle differentiation: role of interleukin-6. Mol. Biol. Cell 15: 2013-2026

23. Natale DR, Paliga AJ, Beier F, D'Souza SJ and Watson AJ (2004) p38 MAPK signaling during murine preimplantation development. Dev. Biol. 268: 76-88

24. Duval D, Reinhardt B, Kedinger $C$ and Boeuf $H$ (2000) Role of suppressors of cytokine signaling (Socs) in leukemia inhibitory factor (LIF)-dependent embryonic stem cell survival. FASEB J. 14: 1577-1584

25. Qi X, Li TG, Hao J, Hu J, Wang J, Simmons H, Miura S, Mishina Y and Zhao GQ (2004) BMP4 supports self-renewal of embryonic stem cells by inhibiting mitogen-activated protein kinase pathways. Proc. Natl. Acad. Sci. USA 101: 6027-6032

26. Adams RH, Porras A, Alonso G, Jones M, Vintersten K, Panelli S, Valladares A, Perez L, Klein R and Nebreda AR (2000) Essential role of p38alpha MAP kinase in placental but not embryonic cardiovascular development. Mol. Cell 6: $109-116$

27. Tamura K, Sudo T, Senftleben U, Dadak AM, Johnson R and Karin M (2000) Requirement for p38alpha in erythropoietin expression: a role for stress kinases in erythropoiesis. Cell 102: 221-231

28. Ihle JN (2000) The challenges of translating knockout phenotypes into gene function. Cell 102: 131-134

29. Allen M, Svensson L, Roach M, Hambor J, McNeish J and Gabel CA (2000) Deficiency of the stress kinase p38alpha results in embryonic lethality: characterization of the kinase dependence of stress responses of enzymedeficient embryonic stem cells. J. Exp. Med. 191: 859-870

30. Viswanathan S, Benatar T, Mileikovsky M, Lauffenburger DA, Nagy A and Zandstra PW (2003) Supplementation-dependent differences in the rates of embryonic stem cell self- renewal, differentiation, and apoptosis. Biotechnol. Bioeng. 84: 505-517

31. Boeuf H, Hauss C, Graeve FD, Baran N and Kedinger C (1997) Leukemia inhibitory factor-dependent transcriptional activation in embryonic stem cells. J. Cell Biol. 138: 1207-1217

32. Niwa $\mathrm{H}$ (2001) Molecular mechanism to maintain stem cell renewal of ES cells. Cell Struct. Funct. 26: 137-148

33. Takekawa M, Adachi M, Nakahata A, Nakayama I, Itoh F, Tsukuda H, Taya $Y$ and Imai $K$ (2000) p53-inducible wip1 phosphatase mediates a negative feedback regulation of p38 MAPK-p53 signaling in response to UV radiation. EMBO J. 19: 6517-6526

34. Yan B, Zemskova M, Holder S, Chin V, Kraft A, Koskinen PJ and Lilly M (2003) The PIM-2 kinase phosphorylates BAD on serine 112 and reverses BADinduced cell death. J. Biol. Chem. 278: 45358-45367

35. Fox CJ, Hammerman PS, Cinalli RM, Master SR, Chodosh LA and Thompson CB (2003The) serine/threonine kinase Pim-2 is a transcriptionally regulated apoptotic inhibitor. Genes Dev. 17: 1841-1854

36. Nagy A and Rossant J (2001) Chimaeras and mosaics for dissecting complex mutant phenotypes. Int. J. Dev. Biol. 45: 577-582

37. Burdon T, Chambers I, Stracey C, Niwa H and Smith A (1999) Signaling mechanisms regulating self-renewal and differentiation of pluripotent embryonic stem cells. Cells Tissues Organs 165: 131-143

38. Boeuf H, Merienne K, Jacquot S, Duval D, Zeniou M, Hauss C, Reinhardt B, Huss- Garcia Y, Dierich A, Frank DA, Hanauer A and Kedinger C (2001) The ribosomal S6 kinases, CAMP-responsive element-binding, and STAT3 proteins are regulated by different leukemia inhibitory factor signaling pathways in mouse embryonic stem cells. J. Biol. Chem. 276: 46204-46211

39. Coucouvanis E and Martin GR (1995) Signals for death and survival: a two-step mechanism for cavitation in the vertebrate embryo. Cell 83: 279-287

40. Aulehla A and Herrmann BG (2004) Segmentation in vertebrates: clock and gradient finally joined. Genes Dev. 18: 2060-2067

41. Robb L and Tam PP (2004) Gastrula organiser and embryonic patterning in the mouse. Semin. Cell Dev. Biol. 15: 543-554

42. Kelly OG, Pinson KI and Skarnes WC (2004) The Wnt co-receptors Lrp5 and Lrp6 are essential forgastrulation in mice. Development 131: 2803-2815

43. Rizzoti K, Brunelli S, Carmignac D, Thomas PQ, Robinson IC and Lovell-Badge $R$ (2004) SOX3 is required during the formation of the hypothalamo-pituitary axis. Nat. Genet. 36: 247-255

44. Rohozinski J and Bishop CE (2004) The mouse juvenile spermatogonial depletion (jsd) phenotype is due to a mutation in the X-derived retrogene, mUtp14b. Proc. Natl. Acad. Sci. USA 101: 11695-11700
45. Fargeas CA, Florek M, Huttner WB and Corbeil D (2003) Characterization of prominin- 2, a new member of the prominin family of pentaspan membrane glycoproteins. J. Biol. Chem. 278: 8586-8596

46. Savatier P, Lapillonne H, Vangrunsven LA, Rudkin B and Samarut J (1996) Withdrawal of differentiation inhibitory activity leukemia inhibitory factor upregulates D-type cyclins and cyclin- dependent kinase inhibitors in mouse embryonic stem cells. Oncogene 12: 309-322

47. Wianny F, Real FX, Mummery CL, Van Rooijen M, Lahti J, Samarut J and Savatier P (1998) G1-phase regulators, cyclin D1, cyclin D2, and cyclin D3: up-regulation at gastrulation and dynamic expression during neurulation. Dev. Dyn. 212: 49-62

48. Burdon T, Smith A and Savatier P (2002) Signalling, cell cycle and pluripotency in embryonic stem cells. Trends Cell Biol. 12: 432

49. Rasmussen TP (2003) Embryonic stem cell differentiation: a chromatin perspective. Reprod. Biol. Endocrinol. 1: 1-7

50. Tachikui H, Kurosawa N, Kadomatsu K and Muramatsu T (1999) Genomic organization and promoter activity of embigin, a member of the immunoglobulin superfamily. Gene 240: 325-332

51. Haendler B, Yamanouchi $\mathrm{H}$, Lessey BA, Chwalisz $\mathrm{K}$ and Hess-Stumpp $\mathrm{H}$ (2004) Cycle- dependent endometrial expression and hormonal regulation of the fibulin-1 gene. Mol. Reprod. Dev. 68: 279-287

52. Huang J, Tan PH, Tan BK and Bay BH (2004) GST-pi expression correlates with oxidative stress and apoptosis in breast cancer. Oncol. Rep. 12: $921-925$

53. Thomenius MJ and Distelhorst CW (2003) Bcl-2 on the endoplasmic reticulum: protecting the mitochondria from a distance. J. Cell Sci. 116: 4493-4499

54. Pinton P, Ferrari D, Rapizzi E, Di Virgilio F, Pozzan T and Rizzuto R (2001) The $\mathrm{Ca} 2+$ concentration of the endoplasmic reticulum is a key determinant of ceramide-induced apoptosis: significance for the molecular mechanism of Bcl-2 action. EMBO J. 20: 2690-2701

55. Kang YJ, Zhou ZX, Wang GW, Buridi A and Klein JB (2000) Suppression by metallothionein of doxorubicin-induced cardiomyocyte apoptosis through inhibition of p38 mitogen-activated protein kinases. J. Biol. Chem. 275: 13690-13698

56. Wang GW, Klein JB and Kang YJ (2001) Metallothionein inhibits doxorubicininduced mitochondrial cytochrome $c$ release and caspase-3 activation in cardiomyocytes. J. Pharmacol. Exp. Ther. 298: 461-468

57. Galceran J, Hsu SC and Grosschedl R (2001) Rescue of a Wnt mutation by an activated form of LEF-1: regulation of maintenance but not initiation of Brachyury expression. Proc. Natl. Acad. Sci. USA 98: 8668-8673

58. Schier AF (2003) Nodal signaling in vertebrate development. Annu. Rev. Cell Dev. Biol. 19: 589-621

59. Raya A and Belmonte JC (2004) Sequential transfer of left-right information during vertebrate embryo development. Curr. Opin. Genet. Dev. 14: 575-581

60. Kubo A, Shinozaki K, Shannon JM, Kouskoff V, Kennedy M, Woo S, Fehling HJ and Keller $G$ (2004) Development of definitive endoderm from embryonic stem cells in culture. Development 131: 1651-1662

61. Esni F, Stoffers DA, Takeuchi T and Leach SD (2004) Origin of exocrine pancreatic cells from nestin-positive precursors in developing mouse pancreas. Mech. Dev. 121: 15-25

62. Wiese C, Rolletschek A, Kania G, Blyszczuk P, Tarasov KV, Tarasova Y, Wersto RP, Boheler KR and Wobus AM (2004) Nestin expression - a property of multi-lineage progenitor cells? Cell Mol. Life Sci. 61: 2510-2522

63. Krakow D, Robertson SP, King LM, Morgan T, Sebald ET, Bertolotto C, Wachsmann-Hogiu S, Acuna D, Shapiro SS, Takafuta T, Aftimos S, Kim CA, Firth $\mathrm{H}$, Steiner CE, Cormier-Daire V, Superti-Furga A, Bonafe L, Graham Jr JM, Grix A, Bacino CA, Allanson J, Bialer MG, Lachman RS, Rimoin DL and Cohn DH (2004) Mutations in the gene encoding filamin B disrupt vertebral segmentation, joint formation and skeletogenesis. Nat. Genet. 36: 405-410

64. Tu Q, Pi M and Quarles LD (2003) Calcyclin mediates serum response element (SRE) activation by an osteoblastic extracellular cation-sensing mechanism. J. Bone. Miner. Res. 18: 1825-1833

65. Hwang R, Lee EJ, Kim MH, Li SZ, Jin YJ, Rhee Y, Kim YM and Lim SK (2004) Calcyclin, a Ca2+ ion-binding protein, contributes to the anabolic effects of simvastatin on bone. J. Biol. Chem. 279: 21239-21247

66. Cho WJ, Kim EJ, Lee SJ, Kim HD, Shin HJ and Lim WK (2000) Involvement of SPARC in in vitro differentiation of skeletal myoblasts. Biochem. Biophys. Res. Commun. 271: 630-634 
67. Delany AM, Kalaizic I, Bradshaw AD, Sage EH and Canalis E (2003) Osteonectin-null mutation compromises osteoblast formation, maturation, and survival. Endocrinology 144: 2588-2596

68. Doetschman TC, Eistetter H, Katz M, Schmidt W and Kemler R (1985) The in vitro development of blastocyst-derived embryonic stem cell lines: formation of visceral yolk sac, blood islands and myocardium. J. Embryol. Exp. Morphol. 87: 27-45

69. Hogan BL, Beddington R, Costantini F and Lacy E (1994) Manipulating the Mouse Embryo. A Laboratory Manual, 2nd edn (Cold Spring Harbor: Cold Spring Harbor Laboratory Press) pp 255-272

70. Duval D, Duval G, Kedinger C, Poch O and Boeuf H (2003) The 'PINIT' motif, of a newly identified conserved domain of the PIAS protein family, is essential for nuclear retention of PIAS3L. FEBS Lett. 554: 111-118

71. Liu WM, Mei R, Di X, Ryder TB, Hubbell E, Dee S, Webster TA, Harrington CA Ho MH, Baid J and Smeekens SP (2002) Analysis of high density expression microarrays with signed-rank call algorithms. Bioinformatics 18 : 1593-1599

72. Hubbell E, Liu WM and Mei R (2002) Robust estimators for expression analysis. Bioinformatics 18: 1585-1592

73. Bolstad BM, Irizarry RA, Astrand M and Speed TP (2003) A comparison of normalization methods for high density oligonucleotide array data based on variance and bias. Bioinformatics 19: 185-193

74. Benjamini Ya HY (1995) Controlling the false discovery rates: a practical and powerful approach to multipl testing. J. Roy. Statist. Soc. B. 57: 289-300

75. Niwa H, Yamamura K and Miyazaki J (1991) Efficient selection for high-expression transfectants with a novel eukaryotic vector. Gene 108: 193-199

76. Stewart CL (1993) Production of chimeras between embryonic stem cells and embryos. Methods Enzymol. 225: 823-855

\section{Supplementary Information accompanies the paper on Cell Death and Differentiation website (http://www.nature.com/cdd)}

